\title{
C5 Gene Mutation
}

National Cancer Institute

\section{Source}

National Cancer Institute. C5 Gene Mutation. NCI Thesaurus. Code C154916.

A change in the nucleotide sequence of the $\mathrm{C} 5$ gene. 